\title{
The Occupational Expectations of Undergraduate Students in the Conservatory Piano Majors
}

\author{
Deniz Beste ÇEVIK KILIÇ ${ }^{1}$, Talia Özlem BALTACILAR BAYOĞLU² \& Ebru GÜNER CANBEY ${ }^{3}$ \\ ${ }^{1}$ Necatibey Education Faculty, Balıkesir University, Balıkesir, Turkey \\ ${ }^{2}$ State Conservatory of Music Department of Piano, Dokuz Eylül University, İzmir, Turkey \\ ${ }^{3}$ State Conservatory of Music Department of Composition and Conducting, Dokuz Eylül University, İzmir, \\ Turkey
}

Correspondence: Deniz Beste ÇEVIK KILIÇ, Necatibey Education Faculty, Balıkesir University, Balıkesir, Turkey. Tel: 90-266-241-1212. E-mail: beste@balikesir.edu.tr

Received: August 10, 2017

doi:10.5539/ies.v11n1p1
Accepted: November 20, 2017 Online Published: December 9, 2017

URL: https://doi.org/10.5539/ies.v11n1p1

\begin{abstract}
An expectation is the belief that a certain action will lead to a given outcome. It is noteworthy to reveal individuals' expectations from their future occupations. The quality and success of education are undoubtedly related to meeting their occupational expectations in the future. In this regard, it is of critical importance to investigate the occupational expectations of undergraduate students in the conservatory piano majors. Therefore, this study aims to reveal the occupational expectations of these students. Semi-structured interviews were conducted with seven students in the study. Based on the results, some suggestions were made for eliminating the elements negatively affecting the occupational expectations of undergraduate students in the conservatory piano majors at least in the education process.
\end{abstract}

Keywords: conservatory piano majors, undergraduate students, expectation

\section{Introduction}

'Expectation' expresses the things that are thought and hoped. An individual's foresight regarding an issue shapes his or her expectation. Victor H. Vroom defines the expectations as "the temporary belief about the likelihood that a particular action will result in a particular outcome (p. 17)." According to a different definition, expectation involves thoughts about success or performance in a particular field in the future based on previous experiences and examples in a similar field (Rotter, 1954). The studies on expectations focus on the variables creating expectations. The effect of independent variables such as previous experiences and an individual's attitude on expectations has been investigated (Feather, 1966). In a study conducted on the expectations regarding the occupational life in the future, previous successes and/or failures were determined to affect occupational expectations (Greenhause, Seidel, \& Marinis, 1983). However, there are also studies highlighting the influence of occupational perceptions of individuals (Bourjaily, 1984) and their university experiences (Dalal \& Singh, 1986) on their expectations. Therefore, university experiences affect not only the occupational expectations but also future expectations. Factors such as successes/failures and the quality of educational environment can lead to changes in their occupational expectations in the early years of the individuals' university education. Biddle et al. (1990) reported in their study that university experience may lead to a change in the perspectives of individuals regarding their lives in the future.

The occupational success of individuals is closely related to their physical characteristics as well as their willful preference for an occupation. The fundamentals regarding occupational acceptance and performing the occupation professionally (occupational awareness) are created in their student years and continue throughout their career. Therefore, it is significant for individuals to start their business life with sufficient occupational awareness to be successful in their business life (Özsoy, 1996). Moreover, the students' rate of success increases as their occupational expectations are met. The results of a study supported this thought (Goodenow \& Grady, 1993). Conversely, when the occupational expectations are not met, there are negative consequences such as dissatisfaction and hopelessness (Fine, 1986). Therefore, it is an undeniable fact that meeting students' occupational expectations has had a great role on their future business life (Umbach \& Porter, 2002). 
A conservatory is defined as "a higher education institution that raises artists in music and performing arts" (YOK, 2006 , p. 16). Conservatories are among the leading institutions regarding directing the art education of the country and shaping the culture. In this regard, music education is of critical importance in conservatories and aims to raise qualified artists. Equipping fundamental skills are among the priority targets in music education. Piano courses are indisputably essential in supporting and developing these fundamental skills. Therefore, occupational piano education that is the foundation of music education in our country starts in primary and secondary education in the conservatories of universities and continues to the graduate level. Thus, the conservatory piano major aims to raise respected musicians who can play as soloists, chamber musicians or orchestra members in national and international artistic activities. Moreover, graduates from the conservatory piano majors can teach piano, correpetition and auxiliary piano courses in conservatories. They can work on the piano staff of the State, Municipality, Foundation or private symphony orchestras or as a correpetitor in the State Opera and Ballet. Thus, the conservatory piano majors students tend to make their occupational preferences in primary or secondary education unlike other disciplines because students work in this long-term education following their early occupation preference. Savickas (1991) reported skills and interest among the factors affecting individual's occupational preferences.

The goals of students and the aims that they wish to realize undoubtedly lead to various expectations from their institutions. Expectations guide students are planning how to meet their needs and realize their aims. Therefore, this study aims to reveal the perspectives of conservatory piano majors undergraduate students regarding their occupational expectations. There have been no previous studies about the occupational expectations of students in the conservatory piano majors. Thus, this study with the aim of revealing students' perspectives regarding their occupational expectations will contribute to the existing studies.

\section{Methodology}

\subsection{Model of the Study}

This study aims to reveal conservatory piano majors undergraduate students' perspectives regarding their occupational expectations. The study used semi-structured interviews based on a qualitative research approach. Qualitative studies are defined by Yin (2003) as investigating a current phenomenon under realistic conditions with a detailed and holistic approach. Merriam (2013) describes it as investigating a limited study while Cresswell (2013) defines it as a design type in which a study can be both a product or object. Qualitative studies put forth in-depth analysis regarding an individual, group, case or problem (Frankel \& Wallen, 1996). Therefore, this study used a qualitative research method to obtain in-depth data regarding students' perspectives.

\subsection{Participants}

Seven undergraduate students from the piano majors of a Conservatory in the West side of Turkey constituted the participants and they were selected through a purposeful sampling technique, which enables the profound investigation of cases that were designated in the research process (Patton, 1997). In this method, the selected sample can represent the research universe by determining the criteria that are significant for the selection (Tavşancil \& Aslan, 2001).

\subsection{Instrument}

A semi-structured interview form developed by the researchers was used in the study. In the semi-structured interview technique, there are some particular questions in the form; however, research can pose new questions in case of need (Yüksel, Mil, \& Bilim, 2007). This technique yields advantages such as the ease of analysis and the chance of self-expression for an interviewer (Büyüköztürk, Kılıç-Çakmak, Akgün, Karadeniz, \& Demirel, 2016)

This interview technique allows interviewees to express their ideas in a more detailed and in-depth way compared with other data collection techniques and enables researchers to see the investigated issue through the interviewees' perspectives (Yıldırım \& Şimşek, 2008). The researchers reviewed the related literature in the development of the semi-structured interview form. To ensure the content validity of the interview form, the opinions of the experts in the field were solicited. The experts were asked to evaluate the questions in the form and ensure that they covered the intended issues and were clear and understandable. The interview questions were reviewed based on the experts' opinions and a pilot study was conducted with the final form. There are four questions in the final form.

Each participant got together for the interview at the date and time determined by the piano instructor and the interviews were conducted at the place where each participant found it appropriate. At the beginning of the interview, general information about the process was reminded to participants. Each interview lasted for 
approximately 30 minutes. Real names were not used in the study. Male students were coded as Male 1, Male 2 and so forth, and female students were coded as Female 1, Female 2 and so forth.

In the study, the participants were asked the following questions:

- What are the reasons for your preference of conservatory piano majors? Please explain.

- What were your expectations from piano majors from the first year you started your education to this period? Which of these expectations has been met and/or not met?

- Could you mention your career goals after your graduation?

- What are the reasons for your preference of this career?

The interviews were conducted by asking each participant the questions and recording their answers with a recorder. A recorder was used to ensure the objectivity in line with Maxwell's descriptive validity criterion (As cited in Sad, 2011, p. 137). To ensure this validity, the credibility that is the representation criterion of the reality in results and the transferability that is the criterion of external validity were used. To increase the credibility of the outcome, the excerpts from the perspectives of the participants about the open-ended questions and these excerpts were attempted to be made from the examples of objective perspectives that reflect the general tendencies in the answer given, rather than the perspectives that would bias the study. The transferability was ensured by presenting the implementation of the study (collecting the data, the characteristics of the participants and data analysis) in a detailed and clear way. This contributed to the transferability of the study (Şencan, 2005). Besides, the reliability was increased by digitizing the qualitative data. McMillian (2002) explains that the most important measure used in the evaluation of the qualitative study is the reliability and validity of data analysis (As cited in Büyüköztürk et al., 2016). According to LeCompte and Goetz (1982), validity is related to the accuracy of results. There are external validity concerns about the instrument yielding similar results when used in similar groups and internal validity concerns about the researcher measuring the intended parameters through the instrument or method. Moreover, reliability is related to the repeatability of research results. External reliability ensures that a research yields similar results in similar environments while internal reliability ensures that other researchers can obtain the same results by using the same data (As cited in Yıldırım \& Şimşek, 2008).

\subsection{Data Analysis}

Descriptive analysis was used to analyze the data obtained by semi-structured interview forms. In the descriptive analysis, data are summarized and interpreted according to pre-determined themes. "Data can be arranged according to the themes set out by research questions and considering questions and themes used in the interview and observation processes" (Yıldırım \& Şimşek, 2008). In the descriptive analysis, participants' answers were first organized and interpreted. Then, the raw data obtained from the interviews were coded and categorized. Finally, the data were classified into different categories and presented in a more meaningful way for readers. The validity was ensured by including excerpts from participants' perspectives. Moreover, the reliability was checked by coding the participants' answers. Miles and Huberman's (1998) formula of inter-coder reliability (reliability $=$ number of agreement/total codes) was used. This reliability was calculated as $84.2 \%$.

\section{Findings}

Under this heading, the findings were presented separately according to the research questions and direct quotations supported the perspectives.

1) Findings including the students' perspectives regarding the reasons for their preference for conservatory piano majors

The findings including students' perspectives regarding the reasons for their preference of conservatory piano majors were presented below. The students' answers are presented in Table 1. In some perspectives, more than one participant expressed some common perspectives.

Table 1. The distribution of students' perspectives regarding the reasons for their preference of conservatory piano majors

\begin{tabular}{llc}
\hline Responses & $\mathrm{f}$ & $\%$ \\
\hline Desire to study professional piano in the future & 1 & 9.1 \\
Desire to be a qualified and equipped pianist & 2 & 18.1 \\
Passion and love for piano & 2 & 18.1 \\
The teacher's guidance and encouragement & & \\
\hline
\end{tabular}




\begin{tabular}{lcc}
\hline $\begin{array}{l}\text { The piano instrument is a polyphonic instrument } \\
\text { Developing the piano technique at an advanced level }\end{array}$ & 1 & 9.1 \\
$\begin{array}{l}\text { and transferring that experience to other individuals } \\
\text { The inadequate piano education obtained in Fine Arts }\end{array}$ & 2 & 9.1 \\
$\begin{array}{l}\text { High School } \\
\text { Parental interest and guidance }\end{array}$ & 1 & 9.1 \\
Total & 11 & 100 \\
\hline
\end{tabular}

As seen in Table 1, the frequency distribution for the students reasons for pursuing piano is as follows: $18.1 \%$ of the students have the passion and love for piano; $18.1 \%$ obtained inadequate piano education in Fine Arts High School; $18.1 \%$ want to be a qualified and equipped pianists; $9.1 \%$ wanted to study professional piano in the future; $9.1 \%$ considered their teachers' guidance and encouragement as the reason for pursuing piano; $9.1 \%$ considered piano as a polyphonic instrument; $9.1 \%$ wanted to develop their piano technique at an advanced level and transfer their experience to other individuals; and 9.1\% cited their parents' interest and guidance as reasons.

Some of the participants' answers regarding the reason to pursue the piano were as follows:

"My passion for piano since childhood drove me here. I chose my occupation at a very young age have never been undecided among other choices. I started this way without any hesitation because conservatories are the most suitable schools for a musician who wishes to pursue a professional piano education" (Female 1)

"I used to love the piano instrument. I wished to develop myself in this field. I started to study the piano as an art by entering the conservatory exam with encouragement from my teacher who noticed this when I was in the fifth grade in the elementary school" (Female 2).

"I decided to pursue my education in a conservatory when I was in the last grade of my elementary education; however, I had been playing the piano for only a few months. The reason for my preference of piano was that it makes feel like there is an orchestra in it even though it is a solo instrument. Although hearing a single voice was like reading a good sentence, hearing multiple voices was like reading an impressive book. I had realized that I was quite inadequate in the piano field when I was in Fine Arts High School. I loved music and felt. I have preferred the conservatory piano majors to pursue a good piano education, develop my technique, reflect what I feel to the piano accurately and comfortably and finally transfer my experiences to others" (Female 3).

2) Findings including the students' perspectives regarding their expectations from piano majors from the first year to this period

The findings including the students' perspectives regarding their expectations from piano majors from the first year to this period are presented below. The students' answers are presented in Table 2. In some perspectives, more than one participant expressed some common perspectives.

Table 2. The distribution of the students' perspectives regarding their expectations from piano majors from the first year to this period

\begin{tabular}{lcc}
\hline Responses & $\mathrm{f}$ & $\%$ \\
\hline $\begin{array}{l}\text { We can say that our expectations were met since our instructors in the } \\
\text { piano majors are qualified and can transfer their knowledge. }\end{array}$ & 2 & 15.3 \\
$\begin{array}{l}\text { At first, we were more motivated. We had bigger ideals and wanted to } \\
\text { feel a better sense of accomplishment. These feelings began to diminish }\end{array}$ & 3 & 23.1 \\
over time. We thought we would be better equipped in the piano \\
majors. We do not think that our expectations were fully met. \\
$\begin{array}{l}\text { The staff limitation in the art department negatively affects me for my } \\
\text { future life. This decreases my motivation. This case does not meet my } \\
\text { expectations. }\end{array}$ \\
$\begin{array}{l}\text { Music courses were given more importance compared to other courses } \\
\text { in the conservatory. However, we think that our knowledge should not } \\
\text { be limited to music and teachers should change their attitudes at this } \\
\text { point. Our expectations were higher in the beginning. }\end{array}$ \\
\hline
\end{tabular}




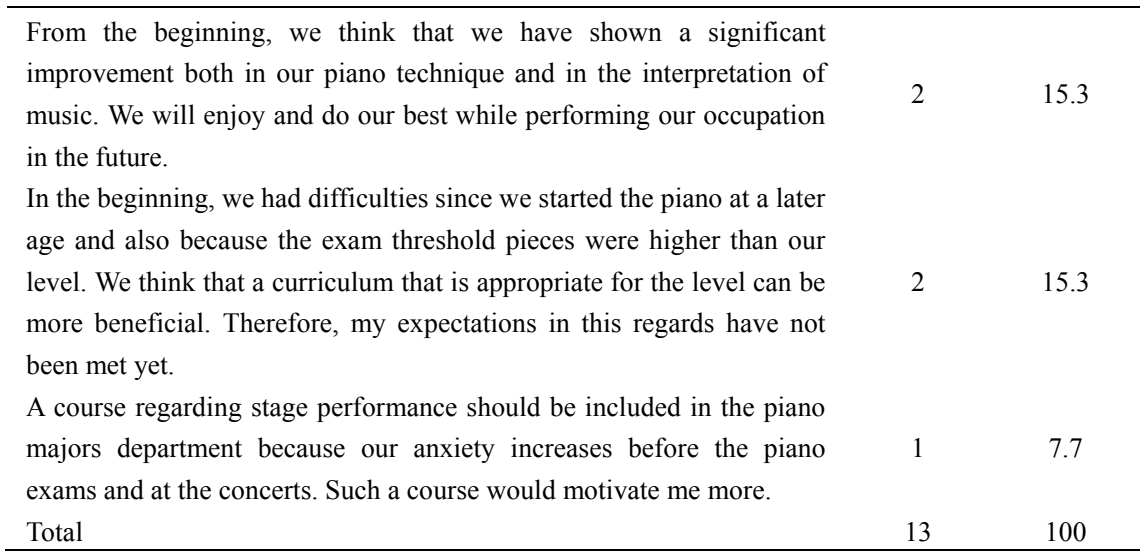

As seen in Table 2, 23.1\% of the participants stated that they thought that they would be more equipped in the beginning but their motivation began to diminish over time and this case negatively affected their expectations. Moreover, $15.3 \%$ stated that their expectations were met since their instructors in the piano majors were qualified and could transfer their knowledge. Another $15.3 \%$ stated that their expectations were higher, in the beginning, the music courses were given more importance compared to other courses in the conservatory and their knowledge should not be limited to music, this case negatively affected their expectations. Furthermore, $15.3 \%$ stated that they showed a significant improvement in both their piano technique and the interpretation of music and would enjoy and do their best while performing their occupation in the future. Some participants $(15.3 \%)$ stated that a curriculum that is appropriate for the level could be beneficial since they started music at a late age while $7.7 \%$ stated that the staff limitation in the piano majors department negatively affected them for their future endeavors and decreased their motivation, thus, negatively affecting their expectations; and 7.7\% stated that a course regarding stage performance should be included in the piano majors department; however, the absence of such a course did not meet their expectations.

Some of the participants' answers to this question are as follows:

"I had a great motivation in the early years of the piano majors department; bigger ideals, more determination to succeed. There was a more hopeful approach. I noticed that my hope has diminished over time. I do not know why and how this happened and what do to; however, I cannot get enough encouragement. When I was in school, I imagined that I would be better equipped (analysis, harmony, music literature, the history of art etc.) and be at a different level. However, I do not see myself competent at present" (Male 1).

"When I started my education in the conservatory, I had high expectations. However, the staff limitation in conservatories negatively affected my motivation and expectations. This situation puts us in a pessimistic attitude towards the occupation as well as impedes our efforts. These reasons greatly demolish our motivation and make us think that I will not be paid for my efforts by inculcating in us a pessimistic attitude while going about our occupation. Moreover, my piano education does not meet my expectations" (Male 2).

"As soon as I graduated, I expected to be able to be a concert pianist. My current occupational expectation, conversely, is to enjoy my occupation give my best performance" (Female 3).

"My initial expectation was to change my incorrect piano technique, my approach and attitude towards the piano. Moreover, I started playing the piano at a very older age than the age at which piano should be started. Therefore, I encountered problems related to this late start. My piano teacher did his best to help me regarding this issue. My expectations in this regard were met" (Male 3).

3) Findings including the students' perspectives regarding their career goals after graduation

The findings including students' perspectives regarding their career goals after graduation are presented below. The students' answers are presented in Table 3. In some perspectives, more than one participant expressed some common perspectives. 
Table 3. The distribution of the students' perspectives regarding their career goals after graduation

\begin{tabular}{lcc}
\hline Responses & $\mathrm{f}$ & $\%$ \\
\hline Being a piano artist & 2 & 10.5 \\
Pursuing an academic career & 6 & 31.5 \\
Making a master's degree & 3 & 15.7 \\
Taking formation lesson and teaching piano & 1 & 5.26 \\
Teaching music in a private school & 1 & 5.26 \\
Giving a private piano lesson & 1 & 5.26 \\
Giving chamber concerts as a piano accompanist & 4 & 21.0 \\
Being able to make my music with the instrument & 1 & 5.26 \\
Total & 19 & 100 \\
\hline
\end{tabular}

As seen in Table 3, after graduation participants wish to: pursue an academic career by $31.5 \%$; give chamber concerts as a piano accompanist by $21.0 \%$; make a master's degree by 15.7 ; be a piano artist by $10.5 \%$; take formation lesson and teach piano by $5.26 \%$; teach music in a private school by $5.26 \%$; give a private piano lesson by $5.26 \%$; and be able to make my own music with the instrument by 5.26 .

Some of the participants' answers to this question are as follows:

"I consider myself qualified enough to be an academician in a university. I plan to pursue an academic career by taking all possible education and adapting experiences and be a piano artist. Therefore, I need to guarantee myself financially" (Female 1).

"My priority after graduation is to make a master's degree. I aim to develop myself more. I want to introduce myself by giving solo concerts" (Male 3).

"I want to give concerts as much as possible. I prefer to be a part of a team. I never think of a solo career because I like being with people. For example, I notice that I have improved a lot when we gave chamber concerts as a piano accompanist. While I am playing only the piano, I feel like I am playing other instruments and I find it enjoyable and efficient to discuss as a group about when to breath or who enters the piece when. We become a family at that point. I feel secure on the stage as well. We share our excitement and feel each other by listening" (Female 3).

4) Findings including the students' perspectives regarding the reasons for their preference of the career

The findings including the students' perspectives regarding the reasons for their preference of the career were presented below. The students' answers were presented in Table 4. In some perspectives, more than one participant expressed some common perspectives.

Table 4. The distribution of the students' perspectives regarding the reasons for their preference of the career

\begin{tabular}{lcc}
\hline Responses & f & $\%$ \\
\hline $\begin{array}{l}\text { I preferred to be a teacher since I took my teacher as a } \\
\text { model. }\end{array}$ & 1 & 7.7 \\
$\begin{array}{l}\text { I preferred to pursue an academic career to be more } \\
\text { qualified. }\end{array}$ & 6 & 46.1 \\
$\begin{array}{l}\text { We will be able to get famous and introduce ourselves } \\
\text { when we become a piano artist. This will yield many } \\
\text { opportunities. }\end{array}$ & 2 & 15.3 \\
$\begin{array}{l}\text { We will prove ourselves and see what we can achieve } \\
\text { by making a master's degree. }\end{array}$ & 3 & 23.1 \\
$\begin{array}{l}\text { I will give private piano lessons since I like to share my } \\
\text { knowledge regarding piano education. }\end{array}$ & 1 & 7.7 \\
Total & 13 & 100 \\
\hline
\end{tabular}

As seen in Table 4, $46.1 \%$ of the participants preferred to pursue an academic career to be more qualified; $23.1 \%$ want to prove themselves and see what they can achieve by obtaining a master's degree; $15.3 \%$ will be able to become famous and introduce themselves when they become a piano artist; therefore, this will yield many opportunities. Moreover, $7.7 \%$ preferred to be a teacher since they considered their teacher as a role model and 
$7.7 \%$ wanted to teach private piano lessons since they wanted to share their knowledge regarding piano education.

Some of the participants' answers to this question were as follows:

"The reason for my preference of this career is my love for teaching. I want to see the progress of my students in the future" (Female 3).

"I prefer to give chamber concerts as a piano artist. I enjoy the music made in a team more than anything else. We are aware of our shortcomings. Moreover, I can meet many people, thus, opening new doors at any moment" (Male 3).

"My piano teacher was the greatest inspiration for my preference of this career. I have always considered him as my role model" (Female 2).

\section{Discussion, Conclusion and Recommendations}

A student who starts the piano majors education in the fifth grade has a total of twelve-year education including four years in elementary school, four years high school and four years in the undergraduate program. During this education, students are expected to gain the basic and advanced piano skills as well as recognition of the piano majors' works by composers of various periods and cultures (YOK, 2016). Moreover, considering the age of onset for piano education in our country, it is possible that the occupational perception, which is not expected to be developed at an early age is shaped by the changes in the expectations within the occupational education process (now longer than ten years). Therefore, this study aims to determine the occupational expectations of students in the piano majors of a Conservatory in the west side of Turkey.

When the students were asked about their perspectives regarding the reasons for their preference of conservatory piano majors, more than one participant expressed common perspectives in three issues and highlighted that their education in Fine Arts High School was insufficient and that they wanted to be a qualified pianist. Çevik (2007) on the insufficiency of piano education reported the importance of students' readiness level to increase the efficiency of piano courses. This result supports the current study. The participants underlined the importance of their love and passion for piano. A different study stressed that students who are happy in their occupations are more successful in their learning experiences as well as in their occupational life (Kömürcü, Erdoğan, \& Eti, 1988). Evans stated that the enthusiasm of piano teachers is very crucial to the learning process of their students. In a different study, the students' perspectives regarding their occupational expectations affected the quality of their education as well as their success during their education (Hussain, Jamil, Noor, Sibtain, \& Shah, 2011). These results are also in concurrence with the current study.

The response of the students regarding the expectations from piano majors from the first year, they started their education in this period; the results revealed that most participants expected to be more equipped; however, their motivation began to diminish over time. Some participants stated that they had higher expectations in the beginning and that music courses should be considered more important compared to other courses in conservatories. Moreover, they indicated that their knowledge should not be limited to music and their expectations were negatively affected in both cases. Other participants stated that their expectations were met since their instructors were qualified and could transfer their knowledge and they showed a significant improvement in both their piano technique and the interpretation of music and their expectations in this regard were met. According to Stanton (1985), an ideal teacher should have strong academic qualifications and expertise and be a researcher who knows the field very well. Stanton's (1985) definition of an ideal teacher supports the current study. Conversely, some participants thought that there is a staff limitation in the piano department and this negatively affected their motivation regarding their occupation; therefore, their expectations were negatively affected. Thus, the students developed a pessimistic perception, which impeded their efforts in finding a job in their field after graduation. Bourjaily (1984) reported a relationship between the individuals' occupational perceptions and expectations. According to a different study, schools have an impact on the occupational expectations (Dalal \& Singh, 1986). Previous studies overlapped with the results of the current study.

During the interviews, the students were asked about their perspectives regarding their career goals after graduation. Most of the participants stated that they wanted to pursue an academic career. Developing occupational qualifications and financial concerns were determined to be among the main motives behind this preference. In a different study, it was revealed that financial concerns were directly correlated with individuals' economic and occupational expectations (Can \& Soyer, 2010). Cevik, Perkmen, Alkan, and Shelley (2013), in their study, focused on the importance of preservice music teachers' sense of success in their occupation and job 
guarantee. These results corroborate the current study. Some participants who wished to give chamber concerts stated their fear of performing solo and sharing a scene with a group made them feel safe and making music by listening to each other improved their skills.

Considering the results including students' perspectives regarding the reasons for their preference of the career, approximately, half of the participants stated that they would be more qualified in playing the piano if they pursued an academic career. Moreover, some stated that they would prove themselves obtaining a master's degree and some indicated that being recognized as a pianist in the future might provide new opportunities in their lives. A different study reported that individuals were satisfied with their occupations and developed a perception that they made the right choice regarding their occupation when needs such as success, recognition and prestige were met (Abd-El-Fattah, 2010). The occupational expectations of the conservatory art students are influenced by their educational program since the conservatory's undergraduate programs provided the necessary knowledge for anoccupation and field of art.

Students' perspectives regarding the usefulness of their knowledge and skills that they acquired in the instrument courses, the feedback from their teachers and the commission where in they perform at the end of each semester regarding their individual performances influences the expectancy levels of students regarding their future occupational life (Jussim, Smith, Madon, \& Palumbo, 1998; Levin \& Nolan, 2000). In this regard, teachers need to positively influence students' musical identity development, which is crucial for them to be a professional musician (Lamont, 2010 as cited in Creech \& Hallem, 2011). Therefore, Hallam (1998) proposed that the student-teacher relationship is very important to understand the students' instrument level and capacity and highlighted that the student-teacher interaction influences students in their whole education life. Zembylas and Papanastasiou (2005) underlined the importance of communication between students and teachers.

Yokus (2010) investigated the effect of using strategies appropriate to the individual characteristics of students for their achievement and revealed that the use of such strategies is more effective compared with traditional strategies. Therefore, designing students' education in a particular field of art according to their needs is of critical importance. Various studies expressed the need for the adaptation of an educational understanding, which considers individual differences (O'brien, 1988; Colwell \& Goolsby, 2002). Therefore, it is an undeniable fact that a student in an educational program that is designed according to the student's will have positive occupational expectations. Moreover, students' expectations will improve in a positive way as they reach the outcomes and targets of the educational program with an increase in their age and grade level.

Based on these findings, the suggestions for eliminating the elements negatively affecting the occupational expectations of undergraduate students in the conservatory piano majors at least in the education process were made as follows:

- The teaching plans and programs of the conservatory piano department should be updated regularly.

- Students and instructors of the piano majors should be included in the works of the department's quality assurance system.

- The current courses about chambers musicians in high school, undergraduate and graduate programs of conservatories should be performed with the various groups consisting of piano and string instrument students and/or wind instruments. Therefore, students in the piano majors are provided to gain experiences of playing with other instruments.

- A mixed concert in which all piano students will participate should be organized in each academic year.

- Conservatory administrators should invite the national and international professional pianists and piano music chambers with the support of the university rectorates as often as the financial sources allow. Through such organizations, students should be allowed to gain experiences.

- Piano major students should be encouraged and informed to participate in both national and international contests that are appropriate for their age and categories by their instructors.

- Students' participation in Erasmus exchange programs should be supported and encouraged.

- Students should be allowed to consult in the career planning unit of their universities and benefit from the necessary professional guidance and network.

- The students who aim to pursue a career focusing on teaching and academic should be encouraged to enroll in a formation certificate program together with the students from other departments. In case that there is a Faculty of Education in the University, the students with a high GPA should be provided to enroll in a certificate program free of charge by the university administration. 


\section{References}

Abd-El-Fattah, S. M (2010). Longitudinal effects of pay increase on teachers' job satisfaction: A motivational perspective. The Journal of International Social Research, 3(10), 11-21.

Biddle, B. J., Bank, B., \& Slavings, R. L. (1990). Modality of thought, campus experiences and the developmentof values. Journal of Educational Psychology, 82(4), 671-682. http://dx.doi.org/10.1037/00220663.82.4.671.

Bourjaily, A. (1984). The relationship among self-concept, achievement and occupational aspirations of high school senior students. Dissertation Abstract International, $45(3), 81$. https://doi.org/10.1007/s40299-013-0153-2

Büyüköztürk, Ş., Kılıç-Çakmak, E., Akgün, Ö. E., Karadeniz, Ş., \& Demirel, F. (2016). Bilimsel araşttrma yöntemleri. Ankara: Pegem Akademi.

Can, Y., \& Soyer, F. (2010). Mesleki ve sosyo-ekonomik beklenti ile yaşam tatmini arasındaki ilişki: Beden eğitimi öğretmenleri üzerinde bir araştırma. Atatürk Üniversitesi Beden Eğitimi ve Spor Bilimleri Dergisi, 4, 28.

Cevik, B., Perkmen, S., Alkan, M., \& Shelley, M. (2013). Who should study music education? A vocational personality approach. Music Education Research, 15(3), 341-356. http://dx.doi.org/10.1080/14613808.2013.788140. https://doi.org/10.1080/14613808.2013.788140

Çevik, D. B. (2007). Piyano öğretimi neden zordur. Atatürk Üniversitesi Kazım Karabekir Eğitim Fakültesi Dergisi, 15, 62-79.

Colwell, R. J., \& Goolsby, T. W. (2002). The teaching of instrumental music (3rd ed.). Upper Saddle River, NJ: Prentice Hall.

Creech, A., \& Hallam, S. (2011). Learning a musical instrument: The influence of interpersonal interaction on outcomes for school-aged pupils. Psychology of Music, 39(1), 102-122. https://doi.org/10.1177/0305735610370222

Creswell, J. W. (2013). Beş nitel araştırma yaklaşımı (Çev. M. Aydın). In M. Bütün, \& S. B. Demir (Çev. Ed.), Nitel araştırma yöntemleri beş yaklaşıma göre nitel araştırma ve araştırma deseni (3. BaskıdanÇev., pp.69-110). Ankara: Siyasal.

Dalal, A. K., \& Singh, R. A. (1986). An integration theoretical analysis of expected job attractiveness and satisfaction. International Journal of Psychology, 21(4-5), 555-564. https://doi.org/10.1080/00207598608247606

Evans, L. (2001). Delving deeper into morale, job satisfaction and motivation among education professionals: Re-examining the leadership dimension. Educational Management Administration \& Leadership, 29(3), 291-306. https://doi.org/10.1177/0263211X010293004

Feather, N. J. (1966). Effects of prior success and failure on expectations of success and subsequentperformance. Journal of Personality and Social Psychology, 3, 287-289. https://doi.org/10.1037/h0022965

Fine, M. (1986). Why urban adolescents drop into and out of public school. Teachers College Record, 87(3), 393-409.

Fraenkel, J. R., \& Wallen, N. E. (1996). How to design and evaluate research in education. New York: McGraw-Hill.

Goodenow, C., \& Grady, K. E. (1993). The relationship of school belonging and friend's values to academic motivation among urban adolescent students. Journal of Experimental Education, 62(1), 60-71. https://doi.org/10.1080/00220973.1993.9943831

Greenhause, J. H., Seidel, C., \& Marinis, M. (1983). The impact of expectations and values on job attitudes. $\begin{array}{llll}\text { Organizational Behavior and Human Performance, 31(3), 394-417. } & \text {. }\end{array}$ http://dx.doi.org/10.1016/00305073(83)90132-0.

Hallam, S. (1998). Instrumental teaching: A practical guide to better teaching and learning. Oxford: Heinemann.

Hussain, L., Jamil, A., Noor, A., Sibtain, M., \& Shah, S. M. A. (2011). Relationship between the professional attitudes of secondary school teachers with their teaching behavior. International Journal of Academic Research in Business and Social Sciences, 1(3), 38-46. 
Jussim, L., Smith, A., Madon, S., \& Palumbo, P. (1998). Teacher expectations. İn J. Brophy (Ed.), Advances in Research on Teaching: Expectation in the Classroom (Vol. 7). London: Ja1 Press Inc.

Kömürcü, N., Erdoğan, N., \& Eti, F. (1988). Marmara Üniversitesi Meslek Yüksekokulu hemşirelik bölümü ilk ögrencilerinin mesleği isteyerek seçip seçmeme durumları ile mezun olabilmeleri arasindaki ilişki. II. Ulusal Hemşirelik Eğitimi Sempozyumu Kitabı, İstanbul (pp. 162-170).

Levin, J., \& Nolan, J. F. (2000). Principles of classroom management: A professional decision-making model (3rd ed.). Boston: Allyn and Bacon.

Merriam, S. B. (2013). Nitelvaka (durum) çalışması (Çev. E. Karadağ). In S. Turan (Çev. Ed.), Nitel araştırma desen ve uygulama için bir rehber (pp. 39-54). Ankara: Nobel.

Miles, L. B., \& Huberman, E. S. (1998). A prospective study of personality characteristics, occupational stressors and burnout among school psychology practitioners. Journal of School Psychology, 36(1), 103-120. https://doi.org/10.1016/S0022-4405(97)00053-8

O’brien, J. (1988). Teaching music. New York: CBS College Publishing.

Özsoy, A. (1996). Hemşire öğrencilerinin mesleğe ilişkin görüşlerinin ileriye dönük incelemesi, 7. Ulusal Hemşirelik Kongresi Bildiri Kitabı, Erzurum (pp. 345-350).

Patton, M. Q. (1997). How to use qualitative methods in evaluation. Newbury Park, CA: SAGE Publications.

Rotter, J. B. (1954). Social learning and clinical psychology. New York: Prentice Hall. https://doi.org/10.1037/10788-000

Şad, S. N. (2011). Illköğretim birinci kademe Ingilizce öğretim programının çocuklara yabancı dil öğretiminin duyuşsal hedeflerini gerçekleştirme düzeyi. Yayımlanmamış doktora tezi. İnönü Üniversitesi Eğitim Bilimleri Enstitüsü, Malatya.

Savickas, M. L. (1991). The meaning of work and love: career issues and interventions. Career Development Quarterly, 39, 315-324. http://doi.org/10.1002/j.2161-0045.1991.tb00299.x

Şencan, H. (2005). Sosyal ve davranıssal ölçümlerde güvenilirlik ve geçerlilik. Ankara: Seçkin.

Stanton, H. (1985). What makes a good teacher? Education news. Australian Education Index, 19.

Tavşancıl, E., \& Aslan, E. (2001). Sözel, yazılı ve diğer materyaller için içerik analizi ve uygulamaörnekleri. İstanbul: Epsilon Yayınevi.

Umbach, P. D., \& Porter, S. R. (2002). How do academic departments impact student satisfaction?: Understanding the contextual effects of departments. Research in Higher Education, 43(2), 209-234. https://doi.org/10.1023/A:1014471708162

Vroom, V. H. (1964). Work and motivation. New York: Wiley.

Yıldırım, A., \& Şimşek, H. (2008). Sosyal bilimlerde nitel araştırma yöntemleri. Ankara: Seçkin Yayıncılık.

Yin, R. K. (2003). Case study research: Design and Methods (3rd ed.). London: Sage.

YOK. (2006). Türkiye Cumhuriyeti Yüksekögretim Mevzuatı. İstanbul: YalınYayıncılık

Yokuş, H. (2010). Piyano eğitiminde öğrenme stratejilerinin kullanılmasının öğrencilerin başarılarına ve üst bilişsel farkındalıklarına etkisi. M. Ü. Atatürk Eğitim Fakültesi Ĕ̆itim Bilimleri Dergisi, 31, 145-160.

Yüksel, A., Mil, B., \& Bilim, Y. (2007). Nitel araştırma: Neden, nasıl, niçin? Ankara: DetayYayıncılık.

Zembylas, M., \& Papanastasiou, E. C. (2005). Modeling teacher empowerment: The role of job satisfaction. Educational Research and Evaluation, 11(5), 433-459. http://doi.org/10.1080/13803610500146152

\section{Copyrights}

Copyright for this article is retained by the author(s), with first publication rights granted to the journal.

This is an open-access article distributed under the terms and conditions of the Creative Commons Attribution license (http://creativecommons.org/licenses/by/4.0/). 